\title{
Pengaruh Variabel Makroekonomi terhadap Pertumbuhan Sukuk Korporasi di Indonesia
}

\section{The Effect of Macroeconomic Variables to Corporate Sukuk Growth in Indonesia}

\author{
Ivan Hannoeriadi Ardiansyah ${ }^{1} \&$ Deni Lubis ${ }^{2}$ \\ ${ }^{1}$ Alumni Departemen Ekonomi Syariah Institut Pertanian Bogor, E-mail: hannoeriadi@gmail.com \\ ${ }^{2}$ Dosen Departemen Ekonomi Syariah Institut Pertanian Bogor, E-mail: denilubis@gmail.com
}

\begin{abstract}
The development of the Islamic financial industry in Indonesia has increased from year to year. This is made possible due to the emergence of varied investment instruments, and corporate sukuk is one good example. Emergence corporate sukuk is expected encourage growth of the national economy. The growth of a good national economy is reflected by good macroecomic variables conditions. Therefore, the government and Bank Indonesia need to maintain inflation stability, money supply, exchange rate and output so that Indonesia can become the largest market center of corporate sukuk issuance. This research aims to analyze the effect of macroeconomic variables towards the growth of corporate sukuk in Indonesia. This research used Ordinary Least Square (OLS) with monthly time series data from January 2013 to December 2015. The results of this research indicate that the money supply, industrial production index, and inflation variables has positive effect (significantly) on the growth of corporate sukuk while exchange rate, oil price, and mudaraba deposit profit-sharing variables have negative effect (significantly).
\end{abstract}

Keywords: Corporate Sukuk, Macroeconomic Variables, OLS

\begin{abstract}
Abstrak. Perkembangan industri keuangan syariah di Indonesia mengalami peningkatan dari tahun ke tahun. Hal ini didukung dengan munculnya berbagai instrumen investasi salah satunya sukuk korporasi. Munculnya sukuk korporasi diharapkan mampu mendorong pertumbuhan perekonomian nasional. Pertumbuhan perekonomian nasional yang baik dicerminkan oleh kondisi variabel makroekonomi yang baik. Oleh karena itu, pemerintah dan Bank Indonesia perlu menjaga stabilitas inflasi, jumlah uang beredar, nilai tukar, dan output sehingga Indonesia dapat menjadi pusat pasar terbesar penerbitan sukuk korporasi. Penelitian ini bertujuan untuk menganalisis pengaruh variabel makroekonomi terhadap pertumbuhan sukuk korporasi di Indonesia. Penelitian ini menggunakan metode Ordinary Least Square (OLS) dengan data deret waktu bulanan dari Januari 2013 sampai dengan Desember 2015. Hasil penelitian ini menunjukkan bahwa variabel jumlah uang beredar, indeks produksi industri, dan inflasi berpengaruh positif (signifikan) terhadap pertumbuhan sukuk korporasi. Variabel kurs, oil price, dan bagi hasil deposito mudharabah berpengaruh negatif (signifikan) terhadap pertumbuhan sukuk korporasi.
\end{abstract}

Kata kunci: OLS, Sukuk Korporasi, Variabel Makroekonomi

\section{Pendahuluan}

\subsection{Latar Belakang}

Indonesia merupakan negara muslim terbesar dunia dengan persentase jumlah penduduk muslim sebesar 87,18 persen (BPS 2010). Potensi ini seharusnya bisa menjadi pasar yang besar bagi industri keuangan syariah di Indonesia. Salah satu bagian dari industri keuangan syariah yang perkembangannya sangat pesat di Indonesia adalah pasar modal syariah. Pasar modal memiliki peran penting bagi perekonomian suatu negara karena pasar modal menjalankan dua fungsi sekaligus, fungsi ekonomi dan keuangan. Hadirnya pasar modal diharapkan aktivitas perekonomian dapat meningkat, karena pasar modal merupakan alternatif pendanaan bagi perusahaan-perusahaan dengan demikian perusahaan dapat 
beroperasi dengan skala yang lebih besar dan pada gilirannya akan meningkatkan pendapatan perusahaan dan kemakmuran masyarakat luas (Darmadji \& Fakhruddin 2001).

Pasar modal syariah muncul pada tahun 1997 dan baru diresmikan pada tahun 2003. Hal itu didukung dengan lahirnya reksa dana oleh PT Danareksa Investment Management pada tahun 1997 dan munculnya Jakarta Islamic Index pada tahun 2000 yang diluncurkan oleh Bursa Efek Indonesia yang bekerja sama dengan PT Danareksa Investment Management. Kedua indeks tersebut hadir dengan tujuan untuk memandu investor yang ingin menanamkan dananya secara syariah. Pasar modal syariah terus berkembang dengan hadirnya Obligasi Syariah PT Indosat Tbk. pada awal September 2002. Obligasi syariah atau sukuk adalah surat berharga jangka panjang berdasarkan prinsip syariah, yang dikeluarkan emiten kepada pemegang obligasi syariah (sukuk), yang mewajibkan emiten untuk membayar pendapatan kepada pemegang obligasi syariah berupa bagi hasil atau margin, serta membayar kembali dana obligasi pada saat jatuh tempo (Fatwa No.32/DSNMUI/IX/2002). Sukuk terbagi menjadi dua jenis, yaitu sukuk yang diterbitkan oleh korporasi dan sukuk yang diterbitkan oleh negara yang lebih dikenal Surat Berharga Syariah Negara (SBSN) atau sukuk global. Sukuk korporasi adalah sukuk yang dikeluarkan oleh perusahaan atau emiten. Sukuk korporasi lebih rentan terhadap perekonomian dan dalam hal gagal bayar terhadap imbal hasil dan pembiayaan pokok perusahaan dari pada SBSN. Oleh sebab itu, perusahaan menawarkan premi gagal bayar. Premi gagal bayar atau kompensasi adalah selisih antara imbal hasil yang dijanjikan dari sukuk korporasi dan SBSN yang serupa. Apabila perusahaan tetap beroperasi dan membayarkan seluruh arus kas yang dijanjikan kepada investor maka investor akan memperoleh imbal hasil lebih besar hingga jatuh tempo dari pada SBSN. Namun, jika perusahaan mengalami kebangkrutan maka sukuk korporasi akan memberikan kerugian lebih besar daripada SBSN. Sukuk mempunyai potensi kerja yang lebih baik maupun buruk dibanding SBSN yang bebas risiko gagal bayar (Bodie et al. 2003). Berdasarkan data yang diperoleh dari Otoritas Jasa Keuangan (2015), pertumbuhan sukuk korporasi dan SBSN di Indonesia mengalami peningkatan tiap tahunnya.

Tabel 1 Jumlah Total Nilai Emisi Sukuk Indonesia 2011 -2015

\begin{tabular}{ccc}
\hline Tahun & $\begin{array}{c}\text { Total Nilai Emisi Sukuk } \\
\text { Korporasi (Rp Triliun) }\end{array}$ & $\begin{array}{c}\text { Total Nilai Emisi SBSN } \\
\text { (Rp Triliun) }\end{array}$ \\
\hline 2011 & 7.9 & 33.3 \\
2012 & 9.7 & 57.0 \\
2013 & 11.9 & 53.0 \\
2014 & 12.9 & 75.5 \\
2015 & 15.9 & 118.5 \\
\hline
\end{tabular}

Sumber: Otoritas Jasa Keuangan (2016)

Tabel 1 memperlihatkan pertumbuhan sukuk yang diterbitkan oleh korporasi dan negara yang tercermin dari total nilai emisi. Pertumbuhan sukuk korporasi dan SBSN mengalami tren yang meningkat dari tahun 2011 sampai dengan tahun 2015. Pertumbuhan sukuk korporasi terbilang lambat dibandingkan dengan SBSN yang mengalami pertumbuhan cepat. Pada tahun 2015, total nilai emisi sukuk korporasi mencapai Rp15.9 triliun meningkat dibandingkan dengan total nilai emisi pada tahun 2011, yaitu Rp7.9 triliun. Sementara itu, pada tahun 2015 total nilai emisi SBSN mencapai Rp118.5 triliun atau meningkat 255.85 persen dibandingkan dengan total nilai emisi pada tahun 2011, yaitu Rp33.3 triliun. 
Perkembangan Nilai Emisi dan Tingkat Pertumbuhan Ekonomi di Indonesia

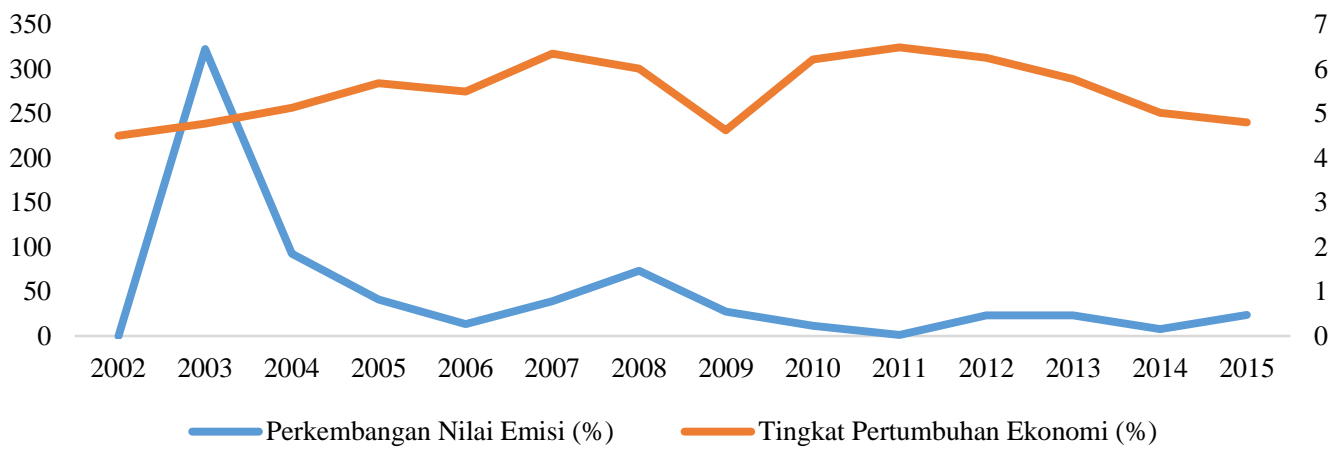

Sumber: Otoritas Jasa Keuangan dan Kementerian Keuangan (diolah)

\section{Gambar 1 Perkembangan Nilai Emisi Sukuk Korporasi dan Tingkat Pertumbuhan Ekonomi di Indonesia}

Gambar 1 memperlihatkan perkembangan nilai emisi sukuk korporasi dan tingkat pertumbuhan ekonomi di Indonesia dari tahun 2002 sampai dengan tahun 2015. Nilai emisi sukuk korporasi adalah total penjumlahan antara emisi sukuk yang masih beredar (outstanding) dan nilai emisi sukuk yang sudah dilunasi. Berdasarkan gambar 1 ada indikasi hubungan positif antara tingkat pertumbuhan ekonomi dengan perkembangan nilai emisi sukuk korporasi. Pada tahun 2002, tingkat pertumbuhan ekonomi menunjukkan hal yang menggembirakan, yaitu berada di angka 4.4 persen naik 0.9 persen dibandingkan tahun sebelumnya. Peningkatan stabilitas ekonomi ini ditandai oleh menguatnya nilai tukar rupiah, menurunnya laju inflasi dan suku bunga, meningkatnya ketahanan fiskal dan cadangan devisa. Pada tahun 2003, stabilitas ekonomi terus meningkat dengan tingkat pertumbuhan ekonomi tercatat di angka 4.9 persen dan perkembangan nilai emisi sukuk korporasi sangat pesat mencapai 322.85 persen, hal tersebut terjadi karena keberhasilan penerbitan sukuk oleh PT Indosat yang menarik perusahaan untuk menerbitkan sukuk. Perkembangan nilai emisi mengalami tren yang fluktuatif, dapat dilihat pada tahun 2006 dimana perkembangannya menurun mencapai 13.58 persen dan pada tahun 2008 mengalami tren yang meningkat mencapai 73.21 persen. Pada tahun 2009 perkembangan nilai emisi sukuk korporasi mengalami tren yang menurun hingga mencapai angka terkecil sebesar 1.28 persen pada tahun 2011. Pada rentang waktu 2009 sampai dengan tahun 2011 terjadi krisis keuangan global yang dapat menjadi penyebab ekonomi mengalami perlambatan dan perkembangan nilai emisi sukuk korporasi menurun. Sampai akhir tahun 2015 perkembangan nilai emisi kembali meningkat mencapai 23.73 persen. Perkembangan nilai emisi sukuk korporasi yang mengalami fluktuatif berbeda dengan total nilai emisi yang mengalami tren meningkat setiap tahunnya.

Perekonomian memengaruhi penerbitan sukuk korporasi. Pertumbuhan perekonomian yang baik dicerminkan oleh kondisi variabel makroekonomi yang baik. Kondisi makroekonomi yang baik dapat mencerminkan iklim investasi yang baik pada suatu negara. Oleh karena itu, perlu dilakukan penelitian yang membahas pengaruh variabel makroekonomi terhadap pertumbuhan sukuk korporasi di Indonesia.

\subsection{Perumusan Masalah}

Perkembangan pasar modal syariah tidak luput dari instrumen investasi salah satunya adalah sukuk. Variabel makroekonomi sangat memengaruhi pertumbuhan sukuk seperti: pertumbuhan ekonomi, jumlah uang beredar, inflasi, pengganguran, dan sebagainya. 
Perubahan yang terjadi pada faktor-faktor makroekonomi dapat memengaruhi penerbitan sukuk. Oleh karena itu, penting bagi emiten atau penerbit sukuk untuk mengetahui faktorfaktor makroekonomi yang memengaruhi penerbitan sukuk dan memperhatikan faktorfaktor tersebut agar penerbitan sukuk dapat berjalan dengan baik

Sasanti (2008) menemukan bahwa pada jangka pendek, variabel ekonomi yang berpengaruh positif terhadap obligasi pemerintah riil adalah obligasi pemerintah rill itu sendiri, suku bunga deposito, nilai tukar riil, laju inflasi, sedangkan yang berpengaruh negatif terhadap obligasi pemerintah riil adalah jumlah uang beredar, pendapatan nasional, suku bunga SBI. Obligasi pemerintah adalah suatu pernyataan utang dari penerbit obligasi yaitu pemerintah kepada pemegang obligasi beserta janji untuk membayar kembali pokok utang beserta kupon bunganya pada saat tanggal jatuh tempo pembayaran. Dalam jangka panjang, variabel yang berpengaruh positif ialah suku bunga SBI dan pendapatan nasional, sedangkan suku bunga deposito berpengaruh negatif.

Rini (2012) menemukan adanya pengaruh negatif yang diberikan oleh inflasi, pengganguran terbuka, dan bonus SBIS terhadap penerbitan sukuk di Indonesia dalam jangka panjang. Pertumbuhan ekonomi dan jumlah uang beredar berpengaruh positif terhadap penerbitan sukuk di Indonesia dalam jangka panjang. Sedangkan dalam jangka pendek variabel tersebut tidak saling memengaruhi.

Penelitian tentang pengaruh variabel makroekonomi terhadap pertumbuhan obligasi pemerintah dan sukuk yang pernah dilakukan Sasanti (2008) dan Rini (2012) terdapat hubungan antara variabel makroekonomi dengan pertumbuhan obligasi pemerintah dan sukuk. Hasil penelitian tersebut menemukan perbedaan pengaruh yang diberikan variabel ekonomi terhadap pertumbuhan obligasi pemerintah dan sukuk di Indonesia serta pada penelitian ini menambahkan variabel indeks produksi industri (IPI), kurs, dan bagi hasil deposito mudharabah terhadap pertumbuhan sukuk di Indonesia.

Kondisi makroekonomi yang baik akan memengaruhi keputusan para emiten untuk menerbitkan sukuk. Berdasarkan perbedaan pengaruh yang diberikan oleh variabel makroekonomi terhadap obligasi pemerintah dan sukuk pada penelitian sebelumnya maka perlu dilakukan penelitian pengaruh variabel makroekonomi terhadap pertumbuhan sukuk korporasi di Indonesia dan faktor variabel makroekonomi yang paling berpengaruh terhadap pertumbuhan sukuk korporasi di Indonesia.

\subsection{Ruang Lingkup}

Penelitian ini mencakup data penerbitan sukuk yang dapat dilihat dari total nilai emisi sukuk korporasi. Nilai emisi sukuk korporasi merupakan total penjumlahan antara emisi sukuk yang masih beredar (outstanding) dan nilai emisi sukuk yang sudah dilunasi. Variabel yang digunakan dalam penelitian ini adalah variabel makroekonomi yang terdiri dari variabel jumlah uang beredar, variabel inflasi, variabel indek produksi industri, variabel kurs, variabel oil price dan variabel bagi hasil deposito mudharabah. Analisis data menggunakan metode Ordinary Least Square (OLS) untuk melihat pengaruh variabel makroekonomi tersebut terhadap pertumbuhan sukuk korporasi di Indonesia, serta mengidentifikasi faktor manakah yang paling memengaruhi pertumbuhan sukuk. Data yang digunakan diperoleh dari website Otoritas Jasa Keuangan, Bank Indonesia, The Organisation for Economic Co-operation and Devolopment (OECD) dan The U.S Energy Information Administration (EIA). Data penelitian ini juga dibatasi dari Januari 2013 sampai dengan Desember 2015. 


\section{Penelitian Terdahulu}

Penelitian yang dilakukan oleh Richard Noviandi Lubis (2009) tentang Analisis Pengaruh Nilai Kurs, Suku Bunga Deposito, dan GDP terhadap permintaan Obligasi Swasta di Indonesia. Data yang digunakan dalam penelitian ini adalah data sekunder dalam bentuk runtun waktu (time series) dengan kurun waktu dari tahun 1997 sampai dengan tahun 2007. Penelitian ini menggunakan model regresi kointegrasi dengan metode kuadrat terkecil (Ordinary Least Square). Hasil penelitian ini menunjukkan bahwa variabel nilai kurs dan GDP memiliki pengaruh positif terhadap peningkatan jumlah permintaan obligasi swastsa di Indonesia sedangkan variabel suku bunga berpengaruh negatif terhadap peningkatan jumlah permintaan obligasi swastsa di Indonesia.

Penelitian yang dilakukan Novie Illya Sasanti (2008) tentang Analisis Pengaruh VariabelVariabel Makroekonomi terhadap Pertumbuhan Obligasi Pemerintah di Indonesia. Model penelitian ini menggunakan metode Vector Auto Regression (VAR) yang dilanjutkan dengan Vector Error Correction Model (VECM) . Hasil dari penelitian menunjukkan bahwa dalam jangka pendek variabel ekonomi yang berpengaruh positif terhadap obligasi pemerintah riil adalah obligasi pemerintah rill itu sendiri, suku bunga deposito, nilai tukar riil, laju inflasi, sedangkan yang berpengaruh negatif terhadap obligasi pemerintah riil adalah jumlah uang beredar, pendapatan nasional, suku bunga SBI sedangkan dalam jangka panjang hanya tiga variabel yang berpengaruh terhadap obligasi pemerintah, karena ada empat persamaan yang terkointegrasi, variabel yang berpengaruh positif terhadap obligasi pemerintah riil adalah suku bunga SBI dan pendapatan nasional, sedangkan yang berpengaruh negatif adalah suku bunga deposito.

Penelitian yang dilakukan oleh Mohammad Agus Khoirul Wafa (2010) tentang Analisa Faktor-Faktor yang memengaruhi Tingkat Permintaan Sukuk Ritel-I (Periode Maret 2009Juni 2010) dengan menggunakan model penelitian analisis regresi menemukan bahwa harga sukuk negara harga sukuk negara ritel, harga obligasi ritel, tingkat bagi hasil deposito bank syariah, dan tingkat suku bunga mempunyai pengaruh yang signifikan terhadap tingkat permintaan sukuk negara ritel pada periode Maret 2009-Juni 2010.

Penelitian yang dilakukan oleh Mustika Rini (2012) tentang Obligasi Syariah (Sukuk) dan Indikator Makroekonomi Indonesia: Sebuah Analisis Vector Error Correction Models (VECM). Model penelitian ini menggunakan metode Vector Error Correction Model (VECM). Hasil dari penelitian menemukan bahwa dalam jangka pendek penerbitan sukuk dan indikator makroekonomi Indonesia yaitu pertumbuhan ekonomi, jumlah uang beredar, inflasi, pengangguran terbuka, dan bonus SBIS tidak saling memengaruhi sedangkan dalam jangka panjang penerbitan sukuk dipengaruhi secara positif oleh pertumbuhan ekonomi dan jumlah uang beredar. Penerbitan sukuk juga dipengaruhi secara negatif oleh inflasi, pengangguran terbuka, dan bonus SBIS.

Penelitian yang dilakukan Novia Handayani Syukma (2011) tentang Analisis FaktorFaktor Makroekonomi yang Mempengaruhi Return Saham Batubara dalam Kelompok Jakarta Islamic Index (JII). Jenis data yang digunakan dalam penelitian ini adalah data sekunder berupa data time series bulanan dari tahun Januari 2005 sampai dengan Mei 2010. Metode analisis yang akan digunakan dalam penelitian ini adalah metode analisis yang bersifat deskriptif dan kuantitatif dengan menggunakan model ekonometrik yaitu ARCHGARCH. Hasil dari penelitian ini menemukan variabel customer price index dan kurs berpengaruh negatif terhadap return saham PT Bumi Resources (BUMI) dan PT Tambang Bukit Asam (PTBA). Variabel indeks produksi industri dan indeks harga saham gabunan berpengaruh positif terhadap return saham BUMI dan PTBA. Variabel jumlah uang beredar dan SBI tidak berpengaruh terhadap return saham BUMI \& PTBA. 
Penelitian yang dilakukan Monjazeb M. dan Ramazanpour E (2013) tentang The Effect of Economic Factors on the Efficiency of Mutual Funds in Iran Seyedeh Javaneh Amhadi Tulamy. Model penelitian ini menggunakan metode Panel Data. Hasil uji panel memperlihatkan bahwa terdapat hubungan positif yang signifikan antara return pembiayaan, exchange rate, dan inflasi. Hasil uji juga memperlihatkan adanya hubungan positif yang signifikan antara aset pembiayaan dan umur pembiayaan dengan return pembiayaan.

Penelitian yang dilakukan Othman et al. (2015) tentang Relationship between Macroeconomic Variables and Net Asset Value (NAV) of Islamic Equity Unit Trust Funds: Cointegration Evidence from Malaysian Unit Trust Industry. Model penelitian ini menggunakan metode Vector Auto Regression (VAR). Hasil dari penelitian ini menemukan bahwa variabel makroekonomi yang dipilih memiliki hubungan jangka panjang dengan Net Asset Value di pasar modal Malaysia. Variabel indeks produksi industri, jumlah uang beredar, exchange rate, oil price, indeks korupsi berpengaruh siginifikan terhadap NAB dalam jangka panjang. Variabel surat utang jangka pendek, pemilihan politik nasional dan krisis keuangan global tidak berpengaruh signifikan terhadap NAV dalam jangka panjang.

Terdapat beberapa aspek perbedaan dalam penelitian ini dengan penelitian sebelumnya. Pertama, sampel yang digunakan dalam penelitian ini berfokus pada Sukuk Korporasi. Kedua, data yang digunakan untuk penelitian ini berupa data time series (deret waktu) dengan periode dari Januari tahun 2013 sampai Desember 2015.

\section{Metode Penelitian}

\subsection{Jenis dan Sumber Data}

Jenis data yang digunakan dalam penelitian ini seluruhnya merupakan datasekunder yang diperoleh dari Otoritas Jasa Keuangan, Bank Indonesia, The Organisation for Economic Co-operation and Devolopment (OECD) dan The U.S Energy Information Administration (EIA). Data yang digunakan adalah data runtun waktu (time series) bulanan dari Januari 2013 sampai dengan Desember 2015. Data yang digunakan adalah data nilai emisi sukuk korporasi, jumlah uang beredar, inflasi, indeks produksi industri, kurs, oil price, dan bagi hasil deposito mudharabah.

Tabel 2 Variabel penelitian

\begin{tabular}{|c|c|c|}
\hline Variabel & Simbol & Sumber Data \\
\hline $\begin{array}{l}\text { Nilai Emisi Sukuk } \\
\text { Korporasi }\end{array}$ & LNSKK & $\begin{array}{l}\text { Otoritas Jasa Keuangan } \\
\text { (OJK) }\end{array}$ \\
\hline Jumlah uang beredar & LNM2 & Bank Indonesia \\
\hline Inflasi & INF & Bank Indonesia \\
\hline Kurs & LNKURS & Bank Indonesia \\
\hline Oil price & LNOP & $\begin{array}{l}\text { The U.S Energy } \\
\text { Information } \\
\text { Administration (EIA) }\end{array}$ \\
\hline $\begin{array}{l}\text { Bagi hasil deposito } \\
\text { mudharabah }\end{array}$ & LNBHDM & $\begin{array}{l}\text { Otoritas Jasa Keuangan } \\
\text { (OJK) }\end{array}$ \\
\hline Indeks produksi industri & LNIPI & $\begin{array}{l}\text { The Organisation for } \\
\text { Economic Co-operation } \\
\text { and Devolopment (OECD) }\end{array}$ \\
\hline
\end{tabular}




\subsection{Model Penelitian}

Metode yang digunakan untuk menganalisis pengaruh variabel makroekonomi terhadap pertumbuhan sukuk korporasi di Indonesia adalah Ordinary Least Square (OLS). Metode regresi linier berganda adalah suatu teknik analisis data yang membahas hubungan antar variabel terikat dengan variabel bebas. Regresi linear berganda merupakan regresi dimana variabel terikat yaitu variabel $\mathrm{Y}$ dalam hal ini adalah nilai emisi sukuk korporasi dihubungkan dengan lebih dari satu variabel bebas. Variabel bebas yang digunakan yaitu, jumlah uang beredar, inflasi, indeks produksi industri, kurs, oil price, dan bagi hasil deposito mudharabah. Persamaan estimasi menggunakan model OLS yang mengadopsi model dari Wycliffe dan Peter Murlu yang dapat dituliskan dalam bentuk sebagai berikut:

$$
Y t=a+\beta_{1} \operatorname{Ln} x_{1}+\beta \operatorname{Ln}_{2} x_{2}+\beta_{3} \operatorname{Ln} x_{3}+\beta_{4} \operatorname{Ln} x_{4}+\beta_{5} \operatorname{Ln} x_{5}+\beta_{6} x_{6}+e
$$

$$
\begin{aligned}
& \text { Keterangan: } \\
& \mathrm{Y}=\text { Nilai emisi sukuk korporasi (persen) } \\
& \text { a } \quad=\text { Konstanta } \\
& \beta \quad=\text { Koefisien regresi variabel independen } \\
& \mathrm{x}_{1} \quad=\text { Oil price (persen) } \\
& \mathrm{x}_{2} \quad=\text { Jumlah uang beredar (persen) } \\
& \mathrm{x}_{3} \quad=\text { Indeks produksi industri (persen) } \\
& \mathrm{x}_{4} \quad=\text { Kurs (persen) } \\
& \mathrm{x}_{5} \quad=\text { Inflasi (persen) } \\
& \mathrm{x}_{6} \quad=\text { Bagi hasil deposito mudharabah (persen) }
\end{aligned}
$$

Definisi dari variabel yang digunakan dalam penelitian ini adalah sebagai berikut:

a. Nilai emisi sukuk korporasi adalah total penjumlahan antara emisi sukuk yang masih beredar (outstanding) dan nilai emisi sukuk yang sudah dilunasi.

b. Indeks Produksi Industri adalah indikator ekonomi yang mengukur perubahan nilai total inflasi yang disesuaikan dengan output produksi.

c. Inflasi adalah proses meningkatnya harga-harga secara umum dan kontinu berkaitan dengan mekanisme pasar yang dapat disebabkan oleh berbagai faktor uang dinyatakan dalam bentuk persen.

d. Kurs menggambarkan nilai tukar uang nasional (Rupiah) terhadap mata uang asing (US\$) yang dinyatakan dalam satuan Rp/ US\$.

e. Oil Price adalah harga minyak dunia.

f. Jumlah uang beredar adalah uang yang beredar di kalangan masyarakat dalam bentuk uang kartal, uang giro, deposito, serta tabungan.

g. Bagi hasil deposito mudharabah adalah nisbah atau proporsi keuntungan antara nasabah dan bank syariah dengan akad mudharabah.

\subsection{Metode Analisis dan Pengolahan Data}

Proses pengolahan data pada penelitian ini dilakukan dengan menggunakan bantuan software Microsoft Excel 2007 dan Eviews 6. Metode analisis data yang digunakan adalah analisis deskriptif dan kuantitatif. Analisis deskriptif digunakan untuk memberikan suatu gambaran secara umum mengenai pertumbuhan sukuk korporasi di Indonesia dan kondisi makroekonomi. Analisis deskriptif dalam penelitian dibantu dengan gambar ataupun tabel agar dapat menjelaskan kondisi rata-rata atau menjelaskan saat masing-masing peubah mengalami kondisi ekstrim tertentu. Metode kuantitatif yang digunakan dalam penelitian ini adalah Ordinary Least Square (OLS). Metode OLS digunakan untuk mengetahui faktor- 
faktor apa saja yang memiliki pengaruh terhadap pertumbuhan sukuk korporasi di Indonesia. Analisis variabel yang paling berpengaruh dalam penelitian ini didasarkan pada nilai koefisien yang paling besar dari hasil estimasi model yang diperoleh.

\subsubsection{Evaluasi Model}

Setelah selesai melakukan pengolahan data, harus dilakukan evaluasi terhadap model estimasi yang dihasilkan. Metode estimasi yang dihasilkan melalui metode analisis Ordinary Least Square (OLS) harus dievaluasi berdasarkan kriteria ekonometrika, kriteria statistika, dan kriteria ekonomi.

\subsection{Uji Kriteria Ekonometrika}

Untuk model regresi linier berganda, ada beberapa asumsi yang harus dipenuhi agar estimator yang dihasilkan memenuhi kriteria Best Linear Unbiased Estimator (BLUE). Uji asumsi tersebut meliputi uji normalitas, uji autokorelasi, uji heteroskedastisitas, dan uji multikolinearitas. Keempat uji tersebut disebut dengan uji asumsi klasik.

\subsubsection{Uji Normalitas}

Uji normalitas adalah uji yang dilakukan untuk menentukan apakah variabel berdistribusi normal atau tidak. Uji normalitas bertujuan untuk mengetahui distribusi data dalam variabel yang akan digunakan dalam penelitian. Data yang baik dan layak digunakan dalam penelitian adalah data yang memiliki distribusi normal. Uji yang digunakan untuk melihat kenormalan data yaitu dengan Jarque-Bera Test atau dengan melihat plot dari sisaan. Hipotesis dalam pengujian normalitas adalah:

$\mathrm{H}_{0}$ : Residual berdistribusi normal

$\mathrm{H}_{1}$ : Residual tidak berdistribusi normal

Dasar penolakan $\mathrm{H}_{0}$ dilakukan dengan membandingkan nilai Jarque-Bera Test dengan taraf nyata $\alpha$ sebesar 0.05 , dimana jika nilai Jarque-Bera Test lebih besar dari taraf nyata $\alpha=5$ persen maka tidak cukup bukti untuk melakukan penolakan terhadap $\mathrm{H}_{0}$, sehingga residual berdistribusi normal.

\subsubsection{Uji Autokorelasi}

Menurut Firdaus (2011), autokorelasi merupakan gangguan pada fungsi regresi yang berupa korelasi di antara faktor gangguan. Autokorelasi lebih mudah timbul pada data time series, karena berdasarkan sifatnya, data masa sekarang dipengaruhi oleh data pada masamasa sebelumnya. Suatu model dikatakan memiliki autokorelasi jika error dari periode waktu yang berbeda saling berkorelasi. Autokorelasi ini akan menyebabkan model menjadi tidak efisien meskipun masih tidak bias dan konsisten.

Pengujian untuk mendeteksi gejala autokorelasi dapat dilakukan dengan menggunakan uji Breusch and Godfrey Serial Correlation Lagrange Multiplier Test dengan hipotesis :

H0 $: \rho=0$ (tidak terdapat serial korelasi)

H1 : $\rho \neq 0$ (terdapat serial korelasi)

Kriteria uji yang digunakan :

- Apabila nilai probability $O b s^{*} R$-squared-nya $>$ taraf nyata $(\alpha)$ yang digunakan, maka persamaan tidak mengalami autokorelasi; 
- Apabila nilai probability $O b s * R$-squared-nya $<$ taraf nyata $(\alpha)$ yang digunakan, maka terdapat autokorelasi dalam persamaan tersebut.

\subsubsection{Uji Heteroskedastisitas}

Suatu model regresi linear harus memiliki varians yang sama (Gujarati 2006). Jika asumsi tersebut tidak terpenuhi, maka akan terdapat masalah heteroskedastisitas. Uji heteroskedastisitas bertujuan untuk menguji apakah dalam sebuah model regresi terjadi ketidaksamaan varian dari residual untuk peubah bebas yang diketahui. Konsekuensi dari adanya heterokedastisitas adalah kemungkinan untuk mengambil kesimpulan yang salah dari Uji F karena pengujian tingkat signifikansi yang kurang kuat. Pengujian yang dapat dilakukan untuk melihat gejala ini adalah dengan menggunakan uji Heteroskedasticity dengan hipotesis:

H0 $: \gamma=0$ (tidak terdapat heteroskedastisitas)

H1 : $\gamma \neq 0$ (terdapat serial heteroskedastisitas)

Kriteria uji yang digunakan :

- Apabila nilai probability $O b s^{*} R$-squared-nya > taraf nyata $(\alpha)$ yang digunakan, maka persamaan tidak mengalami heteroskedastisitas;

- Apabila nilai probability $O b s^{*} R$-squared-nya < taraf nyata $(\alpha)$ yang digunakan, maka terdapat heteroskedastisitas dalam persamaan tersebut.

\subsubsection{Uji Multikolinieritas}

Multikolinearitas adalah kondisi dimana peubah-peubah bebas memiliki korelasi diantara satu dengan yang lainnya. Jika peubah-peubah bebas memiliki korelasi sama dengan satu atau berkorelasi sempurna mengakibatkan koefisienkoefisien regresi menjadi tidak dapat diperkirakan dan nilai standar error setiap koefisien regresi menjadi tak hingga (Purwanto 2011). Untuk mengetahui ada tidaknya multikolinearitas dapat dilihat melalui correlation matrix, dimana batas terjadinya korelasi antar sesama variabel bebas adalah tidak lebih dari |0.80|. Cara untuk mengatasi masalah multikolinearitas antara lain dilakukan dengan menambah data atau mengurangi jumlah data observasi, menambah atau mengurangi jumlah variabel independennya yang memiliki hubungan linear dengan variabel lannya dan mentransformasi variabel. Selain correlation matric, apabila terdapat nilai korelasi yang lebih tinggi dari |0.80|, maka multikoliniearitas dapat diabaikan selama nilai korelasi tersebut tidak melebihi nilai Adjusted Rsquared.

\subsection{Uji Kriteria Statistika}

Uji statistika digunakan untuk memperoleh apakah model yang diterapkan merupakan model yang tepat untuk menggambarkan hubungan antar variabel. Selain itu untuk mengetahui apakah ada hubungan yang siginfikan di antara variabel-variabel independen dengan variabel dependen.

\subsubsection{Uji Koefisien Determinasi $\left(\mathbf{R}^{2}\right)$}

Analisis determinasi dalam regresi linear berganda digunakan untuk menunjukkan seberapa besar prosentase variasi variabel independen yang digunakan dalam model mampu menjelaskan variasi variabel dependen. Jika $\mathrm{R}^{2}$ sama dengan 0 , maka tidak ada sedikitpun prosentase sumbangan pengaruh yang diberikan variabel independen terhadap variabel dependen, atau variasi variabel independen yang digunakan dalam model tidak menjelaskan sedikitpun variasi variabel dependen. Jika $\mathrm{R}^{2}$ sama dengan 1 , maka prosentase sumbangan pengaruh yang diberikan variabel independen terhadap variabel dependen 
adalah sempurna, atau variasi variabel independen yang digunakan dalam model menjelaskan 100 persen variasi variabel dependen.

\subsubsection{Uji Statistik F (Uji Simultan)}

Uji F dilakukan untuk melihat pengaruh variabel-variabel independen secara bersama-sama terhadap variabel dependen. Selain itu dengan uji F ini dapat diketahui pula apakah model regresi linier yang digunakan sudah tepat atau belum. Pengujian ini melihat hasil uji signifikansi yang berada di bawah 5 persen (0.05). Jika nilai sig < 0.05 maka Ho diterima, namun jika nilai sig > 0.05 maka $\mathrm{H}_{0}$ ditolak.

\subsubsection{Uji Statistik t (Uji Parsial)}

Uji t digunakan untuk mengetahui pengaruh variabel independen $(\mathrm{X} 1, \mathrm{X} 2, \ldots \ldots \mathrm{Xn})$ secara sendiri atau masing-masing terhadap variabel dependen (Y). Jika nilai signifikan diatas $\alpha$ $=5$ atau $\alpha=10$ persen berarti masing-masing variabel independen tidak mempunyai pengaruh terhadap variabel dependen. Demikian juga sebaliknya, jika nilai signifikansi berada di bawah nilai $\alpha=5$ atau $\alpha=10$ persen berarti masing-masing variabel independen mempunyai pengaruh terhadap variabel dependen.

\subsection{Uji Kriteria Ekonomi}

Evaluasi model estimasi berdasarkan kriteria ekonomi dilakukan untuk membandingkan kesesuaian tanda dan nilai estimator dengan teori ekonomi dan kesesuaian dengan logika. Pengaruhnya variabel independen terhadap variabel dependen harus dijelaskan dengan penjelasan ekonomi.

\section{Hasil Dan Pembahasan}

\subsection{Gambaran Umum Pertumbuhan Sukuk Korporasi dan Kondisi Makroekonomi di Indonesia}

Perkembangan sukuk korporasi di Indonesia mengalami tren yang fluktuatif. Perkembangan tersebut berbeda dengan total nilai emisi sukuk korporasi dan total jumlah emiten yang mengalami tren meningkat setiap tahunnya. Penerbitan sukuk korporasi pertama dilakukan oleh PT Indosat Tbk dengan total nilai emisi mencapai Rp175 miliar. Penawaran sukuk korporasi yang dilakukan PT Indosat Tbk ini mengalami kelebihan permintaan sampai dua kali lipat. Keberhasilan penerbitan sukuk korporasi dari PT Indosat Tbk diikuti oleh perusahaan lainnya untuk menerbitkan instrumen sejenis.

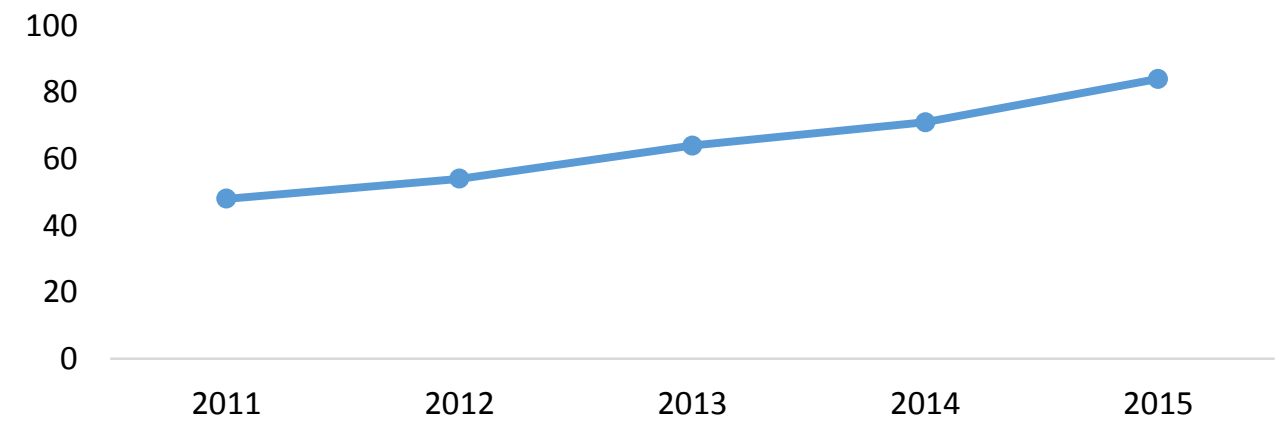

Sumber: Otoritas Jasa Keuangan (OJK)

Gambar 2 Pertumbuhan Total Jumlah Emiten 
Gambar 2 menunjukkan total jumlah emiten tahun 2011 mencapai 48 atau meningkat 47 persen dibandingkan dengan total jumlah emiten pada tahun 2002. Total jumlah emiten mengalami tren yang meningkat dari tahun pertama penerbitan sukuk korporasi. Tren yang meningkat dari tahun pertama disebabkan karena keberhasilan penerbitan sukuk oleh PT Indosat yang menarik perusahaan untuk menerbitkan sukuk. Sampai akhir tahun 2015, total jumlah emiten mencapai 84 dengan total nilai emisi mencapai Rp15.9 triliun atau meningkat sebesar 75 persen dibandingkan dengan tahun 2011.

Perkembangan sukuk korporasi tidak terlepas dari berbagai macam variabel makroekonomi. Makroekonomi adalah studi tentang perekonomian secara menyeluruh, termasuk pendapatan nasional dan perubahan harga. Perubahan harga secara keseluruhan atau inflasi akan berpengaruh terhadap pendapatan nasional.

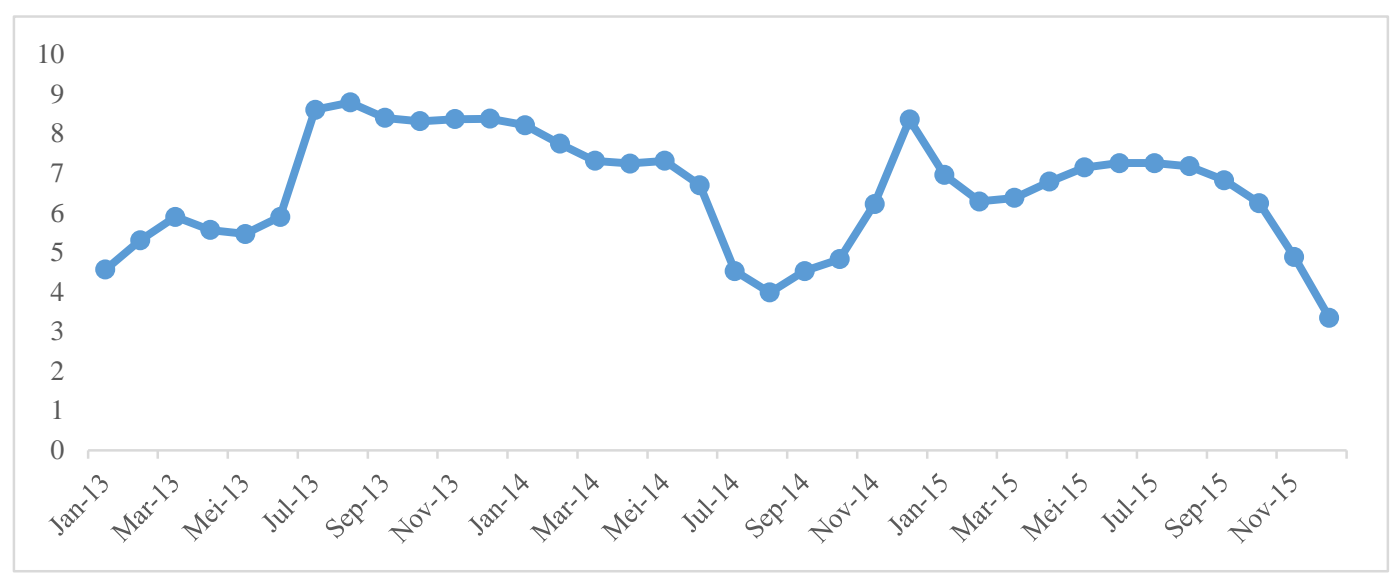

Sumber: Bank Indonesia (BI)

Gambar 3 Tingkat Inflasi di Indonesia

Inflasi dapat berdampak positif dan negatif terhadap pertumbuhan ekonomi. Inflasi berdampak positif apabila angka inflasi kurang dari 10 persen atau bisa disebut inflasi ringan. Gambar 3 melihatkan tingkat inflasi dari bulan Januari 2013 sampai dengan November 2015. Dampak positif inflasi terhadap pertumbuhan ekonomi akan mendorong perusahaan meningkatkan produksi dikarenakan harga yang naik. Peningkatan produksi oleh perusahaan akan menciptakan lapangan kerja yang baru sehingga mampu menyerap tenaga kerja. Penyerapan tenaga kerja berdampak pada naiknya pendapatan nasional sehingga pendapatan per kapita akan meningkat. Meningkatnya pendapatan per kapita akan membuat uang yang berada di masyarakat meningkat sehingga uang yang berlebih tersebut dapat digunakan untuk berinvestasi. 


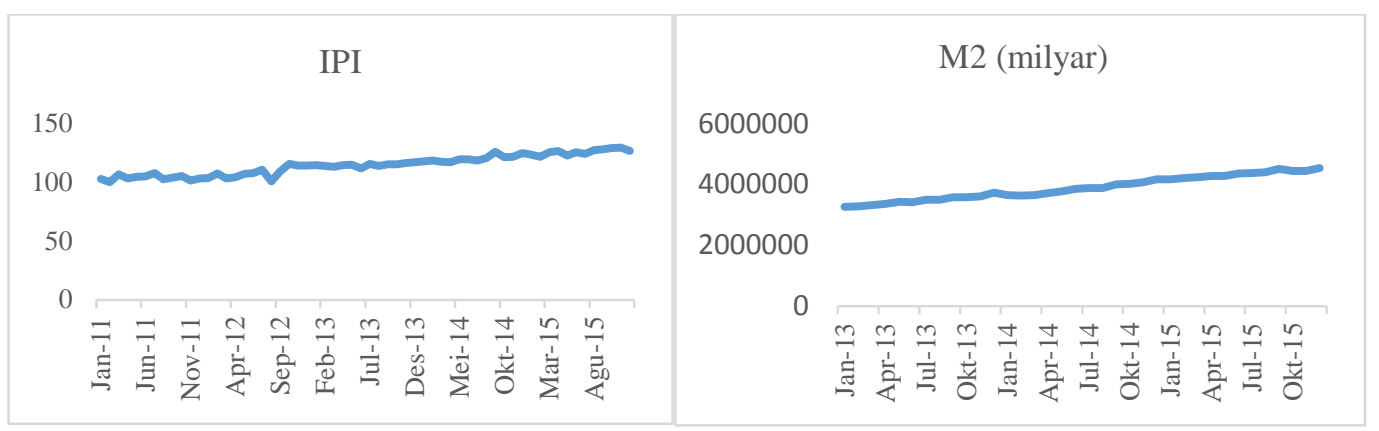

Sumber: Bank Indonesia dan The Organisation for Economic Co-operation and Devolopment (OECD)

\section{Gambar 4 Pergerakan Indeks Produksi Industri dan Jumlah Uang Beredar periode Januari 2013 sampai dengan Desember 2015}

Pengerakan Indeks Produksi Industri dan Jumlah Uang Beredar dalam penelitian ini dapat dilihat pada gambar 4. Variabel indeks produksi industri mengalami tren yang meningkat dari tahun 2011 samapi dengan tahun 2015. Indeks produksi industri terendah terjadi pada bulan Februari 2011 dan tertinggi pada November 2015. Variabel jumlah uang beredar mengalami tren yang terus meningkat dari tahun 2013 sampai dengan tahun 2015. Jumlah uang beredar tumbuh melambat pada Desember 2015 sebesar Rp4 546.7 triliun, atau tumbuh 8.9 persen, melambat dibanding November 2015 yang tumbuh 9.2 persen. Perlambatan pertumbuhan jumlah uang beredar tersebut terutama bersumber dari melambatnya pertumbuhan uang kuasi.

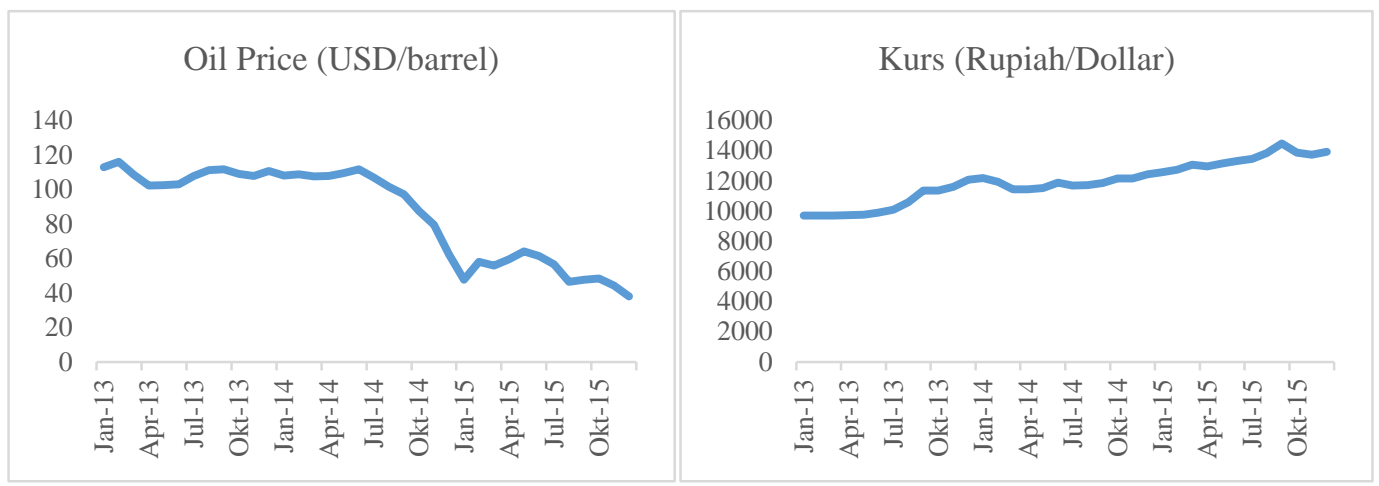

Sumber: Bank Indonesia dan The U.S Energy Information Administration (EIA)

\section{Gambar 5 Pergerakan Oil Price dan Kurs periode Januari 2013 sampai dengan Desember 2015}

Pengerakan Oil Price dan Kurs dalam penelitian ini dapat dilihat pada gambar 5. Pada Juni 2014 harga minyak dunia mengalami penurunan drastis hingga mencapai 47.76 USD per barrel pada Januari 2015. Harga minyak dunia merosot 35 persen sepanjang tahun 2015, hal tersebut terjadi karena permintaan cenderung melambat ditambah produksi global yang terus melonjak hingga akibatnya memangkas harga minyak menuju level terendah. Sepanjang tahun 2013 sampai 2015, kurs rupiah terhadap US Dollar mengalami depresiasi mencapai Rp13 923.75 per USD. Kurs rupiah terhadap US Dollar mengalami depresiasi tertinggi pada September 2015 mencapai Rp 14468 per USD. Terdepresiasinya rupiah terjadi karena menguatnya laju USD, penguatan tersebut terjadi karena turunnya harga minyak dunia dan beberapa komoditas. 


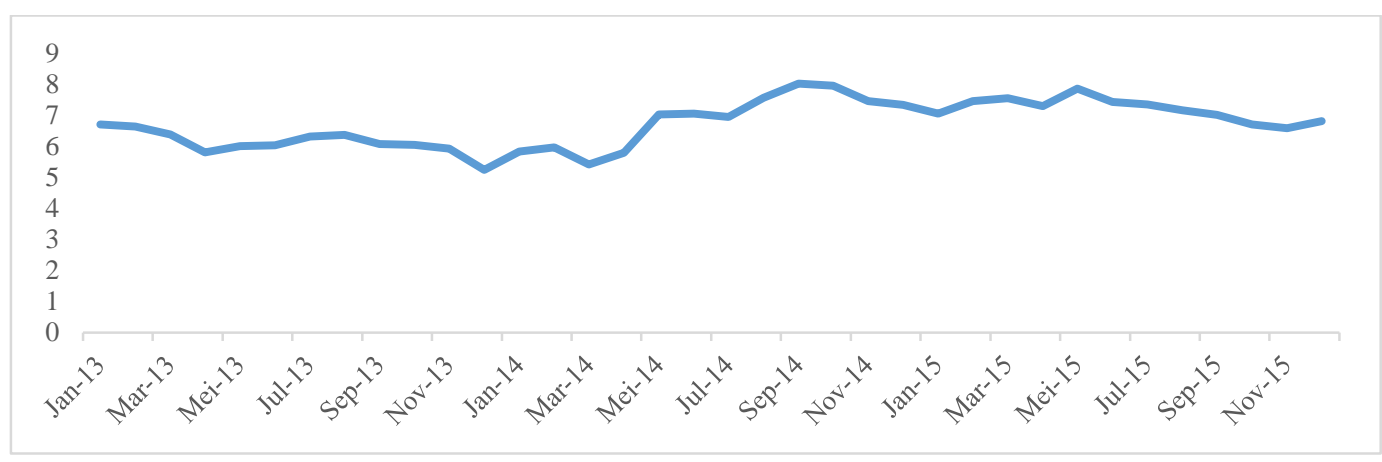

Sumber: Otoritas Jasa Keuangan

\section{Gambar 6 Pergerakan Bagi Hasil Deposito Mudharabah periode Januari 2013 sampai dengan Desember 2015}

Bagi hasil deposito mudharabah mengalami tren yang stabil dari tahun Januari 2013 sampai Desember 2015. Pada gambar 6 bagi hasil deposito mudharabah terrendah terjadi pada bulan Agustus 2011 mecapai 4.43 persen dan tertinggi terjadi pada bulan Desember 2011 mencapai 8.95 persen dan. Hal ini terjadi karena semakin berkembangnya industri keuangan syariah.

\subsection{Indikator Makroekonomi yang Memengaruhi Pertumbuhan Sukuk Korporasi di Indonesia}

Untuk mengetahui faktor-faktor yang memengaruhi pertumbuhan sukuk korporasi di Indonesia dilakukan melalui analisis regresi linier berganda. Dalam hal ini akan dikaji bagaimana variabel independen yang ada dapat mempengaruhi variabel dependen. Model estimasi yang dihasilkan harus dievaluasi berdasarkan kriteria ekonometrika, kriteria statistika, dan kriteria ekonomi.

\subsubsection{Tahapan Evaluasi Model Berdasarkan Kriteria Ekonometrika}

Pengujian asumsi klasik dilakukan agar model dapat menghasilkan estimator yang memenuhi kriteria Best Linear Unbiased Estimator (BLUE). Pengujian asumsi klasik meliputi uji normalitas, uji autokorelasi, uji heteroskedastisitas dan uji multikoliniearitas.

\section{Uji Normalitas}

Pengujian normalitas dilakukan dengan Jarque-Bera Test yang terdapat dalam software Eviews 6. Hasil perhitungan dengan menggunakan software Eviews 6 menghasilkan output lamnilai Jarque-Bera sebesar 0.574734. Hal tersebut menandakan bahwa nilai Jarque-Bera lebih besar dari taraf nyata 5 persen. Jarque-Bera yang lebih besar dari taraf nyata 5 persen menandakan tidak cukup bukti untuk melakukan penolakan terhadap $\mathrm{H}_{0}$, dan mengindikasikan residual berdistribusi normal. Berdasarkan hasil tersebut dapat disimpulkan bahwa kriteria normalitas model estimasi telah terpenuhi.

\section{Uji Autokorelasi}

Pengujian autokorelasi pada perangkat Eviews 6 dapat diketahui melaui Serial Corelation $L M$ test, dimana nilai probability obs*R-squared harus lebih besar dari nilai kritis $(\alpha)$. Nilai probability obs $* R$-squared pada model persamaan adalah 0.0540 yang artinya bernilai lebih besar dari $\alpha=5$ persen. Hal ini menunjukkan bahwa model persamaan yang digunakan dalam penelitian ini tidak memiliki masalah autokorelasi. Hasil uji tersebut dapat dilihat pada Tabel 3 berikut. 
Tabel 3 Hasil Uji Autokorelasi

\begin{tabular}{lcll}
\hline \multicolumn{4}{l}{ Breusch-Godfrey Serial Correlation LM Test: } \\
\hline F-statistic & 2.613341 & Prob. F(2,27) & 0.0917 \\
Obs*R-squared & 5.838657 & Prob Chi-Square(2) & 0.0540 \\
\hline
\end{tabular}

\section{Hasil Uji Heteroskedastisitas}

Pengujian autokorelasi pada perangkat Eviews 6 dapat diketahui melaui uji White, dimana nilai probability obs $* R$-squared harus lebih besar dari nilai kritis $(\alpha)$ yang digunakan. Hasil pengujian menunjukkan bahwa nilai probability obs*R-squared pada model persamaan adalah 0.5503 yang artinya bernilai lebih besar dari $\alpha=5$ persen. Oleh karena itu, model persamaan yang digunakan dalam penelitian ini tidak memiliki masalah heteroskedastisitas. Hasil uji tersebut dapat dilihat pada Tabel 4 berikut.

\section{Tabel 4 Hasil Uji Heteroskedastisitas}

\begin{tabular}{lcll}
\hline Heteroskedasticity Test: White & & \\
\hline F-statistic & 0.783673 & Prob. F(22,13) & 0.7029 \\
Obs*R-squared & 20.52422 & Prob. Chi-Square(22) & 0.5503 \\
Scaled explained SS & 16.61276 & Prob. Chi-Square(22) & 0.7844 \\
\hline
\end{tabular}

\section{Hasil Uji Multikolinearitas}

Persyaratan kecukupan (sufficient condition) untuk terbebas dari pelanggaran asumsi multikolinearitas ini adalah nilai koefisien antara variabel independen pada model tidak melebihi nilai $\mathrm{R}^{2}$. Hasil perhitungan nilai koefisien korelasi dengan menggunakan software Eviews 6 menghasilkan output nilai koefisien korelasi yang tidak melebihi nilai $\mathrm{R}^{2}$ sebesar 0.95 pada variabel independen dalam model, dengan demikian persyaratan kecukupan telah terpenuhi sehingga dapat disimpulkan bahwa tidak terjadi pelanggaran asumsi multikolinearitas dalam estimasi model penelitian.

\subsubsection{Tahapan Evaluasi Model Berdasarkan Kriteria Statistika}

Berdasarkan hasil analisis data diperoleh nilai koefisien determinasi $\left(\mathrm{R}^{2}\right)$ pada model yaitu 0.95 . Nilai tersebut menandakan bahwa 95 persen keragaman dari variabel dependen dapat dijelaskan oleh variabel-variabel independennya, sedangkan sisanya sebesar 5 persen dijelaskan oleh variabel lain di luar model. Dari hasil estimasi diketahui nilai Prob (FStatistic) pada model memiliki nilai 0.000000 yang lebih kecil dibandingkan taraf nyata $\alpha$ sebesar 5 persen sehingga dapat disimpulkan bahwa setidaknya ada satu variabel independen yang berpengaruh signifikan terhadap pertumbuhan sukuk korporasi di Indonesia dengan tingkat kepercayaan 95 persen. Uji-t dilakukan untuk melihat masingmasing variabel bebas secara statistik berpengaruh nyata terhadap pertumbuhan sukuk korporasi di Indonesia. Uji tersebut dapat dilakukan dengan melihat nilai $t$-statistic dari masing-masing variabel yang lebih kecil dari taraf nyata $\alpha=5$ persen. Variabel independen oil price, jumlah uang beredar, kurs, dan inflasi memiliki nilai probabilitas lebih kecil daripada taraf nyata $\alpha=5$ persen. Hal ini berarti variabel-variabel independen tersebut secara parsial berpengaruh signifikan terhadap pertumbuhan sukuk korporasi di Indonesia. Variabel indeks produksi industri dan bagi hasil deposito mudharabah memiliki nilai probabilitas lebih besar dari $\alpha=5$ persen namun memiliki memiki nilai probabilitas lebih kecil daripada taraf nyata $\alpha=10$ persen. Hasil ini berarti variabel indeks produksi industri dan bagi hasil deposito mudharabah secara parsial berpengaruh signifikan pertumbuhan sukuk korporasi di Indonesia. 


\subsubsection{Tahapan Evaluasi Model Berdasarkan Kriteria Ekonomi}

Estimasi model yang diperoleh dari hasil pengolahan data menunjukkan hasil cukup baik karena telah memenuhi syarat-syarat pengujian model. Selanjutnya, evaluasi dengan kriteria ekonomi perlu dilakukan dengan melihat tanda dan besaran masing-masing variabel bebas. Berdasarkan hasil estimasi yang diperoleh melalui metode OLS, empat dari enam variabel yang digunakan secara parsial berpengaruh signifikan terhadap pertumbuhan sukuk korporasi di Indonesia di Indonesia. Tabel 5 menyajikan hasil estimasi untuk masing-masing variabel dalam model.

Tabel 5 Hasil Estimasi Model

\begin{tabular}{lcl}
\hline Variabel & Koefesien & Probabilitas \\
\hline LNOP & $-0.295251^{* *}$ & 0.0103 \\
LNM2 & $1.129544^{*}$ & 0.0000 \\
LNIPI & $0.414472^{* * *}$ & 0.1000 \\
LNER & $-0.609043^{* *}$ & 0.0111 \\
INF & $0.035210^{*}$ & 0.0000 \\
BHDM & $-0.015473^{* * *}$ & 0.0711 \\
C & -2.792825 & 0.0114 \\
\hline R-Squared & 0.956709 & \\
\hline Prob (F-Statistik) & 0.000 & \\
\hline Keterangan: & $*$ ) signifikan pada taraf nyata 1\% & \\
& $* *$ ) signifikan pada taraf nyata 5\% &
\end{tabular}

\subsection{Pengaruh oil price terhadap pertumbuhan sukuk korporasi di Indonesia}

Variabel oil price berpengaruh negatif dan signifikan pada taraf nyata $5 \%(\alpha=0.05)$ terhadap pertumbuhan sukuk korporasi di Indonesia dan memiliki koefisien -0.29. Artinya, jika terjadi kenaikan oil price sebesar satu persen maka akan menyebabkan pertumbuhan sukuk korporasi menurun sebesar 0.29 persen pada taraf nyata 5 persen. Kenaikan harga minyak dunia dapat memengaruhi inflasi dari sisi Supply (cost push inflation), kenaikan harga minyak menyebabkan peningkatan biaya produksi barang dan jasa. Peningkatan biaya produksi ini akan memicu terjadinya inflasi. Peningkatan pada tingkat inflasi akan menyebabkan pendapatan riil masyarakat berkurang sehingga akan menurunkan keinginan melakukan investasi. Turunnya keinginan masyarakat untuk melakukan investasi ini akan berdampak pada investasi di pasar modal. Hal ini akan menyebabkan turunnya pertumbuhan sukuk korporasi di Indonesia. Hasil penelitian ini sesuai dengan hipotesis penelitian dan dengan penelitian sebelumnya yang dilakukan oleh Othman et al. (2015).

\subsection{Pengaruh jumlah uang beredar terhadap pertumbuhan sukuk korporasi di Indonesia}

Variabel jumlah uang beredar berpengaruh positif dan signifikan pada taraf nyata $1 \%(\alpha=$ 0.01) terhadap pertumbuhan sukuk korporasi di Indonesia dan memiliki koefisien 1.12. Artinya, jika terjadi kenaikan jumlah uang beredar sebesar satu persen maka akan menyebabkan pertumbuhan sukuk korporasi meningkat sebesar 1.12 persen. Hal ini sesuai dengan hipotesis bahwa ketika terjadi peningkatan pada jumlah uang beredar maka penerbitan sukuk akan mengalami kenaikan karena selain sebagai sumber dana untuk menutupi defisit anggaran perusahaan dan sebagai dana untuk membiayai pembangunan infrastruktur, penerbitan sukuk juga dapat digunakan sebagai salah satu instrumen dalam operasi pasar terbuka. Operasi pasar terbuka ini salah satu cara untuk mengendalikan jumlah uang yang beredar. Selain itu peningkatan jumlah uang beredar di masyarakat akan membuat masyarakat memilih untuk membeli sukuk korporasi dikarenakan meningkatnya 
inflasi. Masyarakat memilih untuk mempertahankan nilai uangnya dalam bentuk sukuk korporasi dibandingkan memegang uang yang nilai riilnya akan terus menurun seiring terjadinya peningkatan inflasi. Hasil penelitian ini sesuai dengan hipotesis penelitian dan dengan penelitian sebelumnya yang dilakukan Rini (2012).

\subsection{Pengaruh kurs terhadap pertumbuhan sukuk korporasi di Indonesia}

Variabel kurs berpengaruh negatif dan signifikan pada taraf nyata $5 \%(\alpha=0.05)$ terhadap pertumbuhan sukuk korporasi di Indonesia dan memiliki koefisien -0.6. Artinya, jika terjadi kenaikan kurs sebesar satu persen maka akan menyebabkan pertumbuhan sukuk korporasi menurun sebesar 0.6 persen pada taraf nyata 5 persen. Temuan ini sejalan dengan peneltian yang dilakukan Syukma (2011) dan Othman et al. (2015) yang menyatakan bahwa jika mata uang suatu negara terapresiasi terhadap dolar AS, akan menyebabkan penurunan permintaan produk ekspor karna harganya lebih mahal dari negara-negara eksportir lainnya. Hal ini akan menyebabkan capital outflow. Capital outflow akan menurunkan investasi dan akan berdampak terhadap turunnya pertumbuhan sukuk korporasi di Indonesia.

\subsection{Pengaruh inflasi terhadap pertumbuhan sukuk korporasi di Indonesia}

Variabel inflasi berpengaruh positif dan signifikan pada taraf nyata $1 \%(\alpha=0.01)$ terhadap pertumbuhan sukuk korporasi di Indonesia dan memiliki koefisien 0.35. Artinya, jika terjadi kenaikan inflasi sebesar satu persen maka akan menyebabkan pertumbuhan sukuk korporasi meningkat sebesar 0.35 persen. Peningkatan inflasi menyebabkan masyarakat akan memilih untuk mempertahankan nilai uangnya melalui pembelian sukuk korporasi dibandingkan memegang uang yang nilai riilnya akan terus menurun seiring terjadinya peningkatan inflasi. Hasil penelitian ini sesuai dengan hipotesis penelitian dan dengan penelitian sebelumnya yang dilakukan Monjazeb \& Ramazanpour (2013).

\subsection{Pengaruh indeks produksi industri terhadap pertumbuhan sukuk korporasi di Indonesia}

Variabel indeks produksi industri berpengaruh positif dan signifikan pada taraf nyata $10 \%$ $(\alpha=0.1)$ terhadap pertumbuhan sukuk korporasi di Indonesia dan memiliki koefisien 0.41. Artinya, jika terjadi kenaikan indeks produksi industri satu persen maka akan menyebabkan pertumbuhan sukuk korporasi meningkat sebesar 0.41 persen. Indeks produksi industri mencerminkan aktivitas ekonomi secara riil sehingga memengaruhi secara langsung arus kas perusahaan. Jika IPI meningkat maka pendapatan perusahaan meningkat begitu pula dengan pendapatan masyarakat. Peningkatan pendapatan masyarakat berdampak positif bagi permintaan sukuk korporasi. Permintaan sukuk korporasi akan mendorong pertumbuhan perekonomian nasional dari sisi investasi. Hasil ini sesuai dengan penelitian yang dilakukan Othman et al. (2015) yang menyatakan bahwa pasar ekuitas sangat sensitif terhadap perubahan indeks produksi industri.

\subsection{Pengaruh bagi hasil deposito mudharabah terhadap pertumbuhan sukuk korporasi di Indonesia}

Variabel bagi hasil deposito mudharabah berpengaruh negatif dan signifikan pada taraf nyata $10 \%(\alpha=0.1)$ terhadap pertumbuhan sukuk korporasi di Indonesia dan memiliki koefisien -0.01. Artinya, jika terjadi kenaikan bagi hasil deposito mudharabah satu persen maka akan menyebabkan pertumbuhan sukuk korporasi menurun sebesar 0.01 persen. Temuan ini sejalan dengan penelitian yang dilakukan Listya (2015) yang menyatakan seiring berjalannya waktu, nisbah bagi hasil yang diberikan deposito mudharabah semakin kompetitif, sehingga pengaruhnya terhadap keputusan masyarakat untuk menempatkan dananya pada deposito mudharabah semakin besar. Sukuk koporasi perlu memberikan 
imbalan yang cukup kompetitif sehingga masyarakat tertarik untuk untuk berinvestasi dengan sukuk korporasi.

\section{Kesimpulan dan Saran}

Berdasarkan perumusan masalah dalam penelitian ini, maka hasil analisis pengaruh variabel makroekonomi terhadap pertumbuhan sukuk korporasi di Indonesia dapat disimpulkan bahwa kondisi variabel makroekonomi mempengaruhi pertumbuhan sukuk korporasi. Variabel jumlah uang beredar, indeks produksi industri, dan inflasi berhubungan positif terhadap pertumbuhan sukuk korporasi di Indonesia sedangkan oil price, kurs, dan bagi hasil deposito mudharabah berpengaruh negatif.

Hasil OLS menunjukkan bahwa variabel oil price, jumlah uang beredar, kurs, inflasi, indeks produksi industri, dan bagi hasil deposito mudharabah berpengaruh signifikan terhadap pertumbuhan sukuk korporasi di Indonesia. Variabel yang memiliki pengaruh paling besar terhadap pertumbuhan sukuk korporasi di Indonesia adalah jumlah uang beredar. Variabel pada penelitian ini memiliki pengaruh yang signifikan sehingga secara langsung akan mendorong pertumbuhan ekonomi nasional.

Berdasarkan simpulan dan hasil penelitian yang telah dilakukan, maka beberapa saran yang dapat diberikan dari penelitian ini adalah sebagai berikut:

1. Bank Indonesia (BI) perlu menjaga stabilitas dari jumlah uang beredar dan kurs karena jumlah uang beredar memiliki pengaruh paling besar terhadap pertumbuhan sukuk korporasi dan kurs memberikan pengaruh yang negatif terhadap pertumbuhan sukuk korporasi di Indonesia.

2. Untuk penelitian selanjutnya perlu menambah variabel lain yang relevan memengaruhi pertumbuhan sukuk korporasi di Indonesia seperti pengangguran.

\section{Daftar Pustaka}

[BI] Bank Indonesia. 2016. Inflasi [Internet]. [diunduh 2016 September 8]. Tersedia pada: http://www.bi.go.id

http://www.bi.go.id

2016. Kurs [Internet]. [diunduh 2016 September 8]. Tersedia pada:

2016. M2 [Internet]. [diunduh 2016 September 8]. Tersedia pada: http://www.bi.go.id

Bodie, et al. 2003. Essential of Investments. International Edition, McGrawn-Hill, New York.

[BPS] Badan Pusat Statistik. 2016. Jumlah Penduduk Muslim [Internet]. [diunduh 2016 September 5]. Tersedia pada: https://www.bps.go.id

[EIA] The U.S Energy Information Administration. 2016. Data Oil Price 2011-2015 [Internet]. [diunduh 2016 September 10]. Tersedia pada: http://www.eia.gov/

Firdaus M. 2011. Ekonometrika Suatu Pendekata Aplikatif. Jakarta (ID): PT.Bumi Aksara.

Darmadji, T dan Fakhruddin, H. 2001. Pasar Modal di Indonesia. Jakarta: Salemba Empat

Lubis, Richard Noviandi. 2009. Analisis Pengaruh Nilai Kurs, Suku Bunga Deposito, dan GDP terhadap permintaan Obligasi Swasta di Indonesia [skripsi]. Medan (ID): Universitas Sumatera Utara 
Monjazeb M, Ramazanpour E. 2013. The Effect of Economic Factors on The Efficiency of Mutual Funds in Iran Seyedeh Javaneh Ahmadi Tulamy. Technical Journal of Engineering and Applied Sciences. Vol 3(15): 1707- 1711.

MUI. 2001. Fatwa Dewan Syariah Nasional (DSN) No.32/DSN-MUI/IV/2002. Jakarta: MUI.

[OECD] The Organisation for Economic Co-operation and Devolopment. 2016. Data Indeks Produksi Industri 2011-2015 2015 [Internet]. [diunduh 2016 September 10]. Tersedia pada: http://www.oecd.org

[OJK] Otoritas Jasa Keuangan. 2016. Data Bagi Hasil Deposito Mudharabah 2011-2015 [Internet]. [diunduh 2016 September 10]. Tersedia pada: http://www.ojk.go.id

[OJK] Otoritas Jasa Keuangan. 2016. Data Sukuk 2011-2015 [Internet]. [diunduh 2016 September 10]. Tersedia pada: http://www.ojk.go.id

Rini, Mustika. 2002. Obligasi Syariah (Sukuk) dan Indikator Makroekonomi Indonesia: Sebuah Analisis Vector Error Correction Models (VECM) [skripsi]. Bogor (ID): Institut Pertanian Bogor.

Othman, Kameel A, Aziz AH. 2015. Relationship Between Macroeconomic Variables and Net Asset Value (NAV) of Islamic Equity Unit Trust Funds: Cointegration Evidence from Malaysian Unit Trust Industry. Journal of Business and Social Science Review. Vol 1(2) : 327-339.

Sasanti, Novie Illya. 2008. Analisis Pengaruh Variabel-Variabel Makroekonomi terhadap Pertumbuhan Obligasi Pemerintah di Indonesia [skripsi]. Bogor (ID): Institut Pertanian Bogor.

Syukma, Novia Handayani. 2011. Analisis Faktor-Faktor Makroekonomi yang Mempengaruhi Return Saham Batubara dalam Kelompok Jakarta Islamic Index (JII) [skripsi]. Bogor (ID): Institut Pertanian Bogor.

Wafa, Mohammad Agus Khoirul. 2010. Analisa Faktor-Faktor yang memengaruhi Tingkat Permintaan Sukuk Ritel-I (Periode Maret 2009-Juni 2010). La_Riba. Volume IV, Desember 2010: 161-178. 